\title{
Treasurer's Report
}

Perhaps 1996 could have been better financially for the Materials Research Society (MRS), but it is difficult to imagine how. The highlights your Treasurer would like you to know are the stellar success of meetings and other elements in the 1996 Operating Budget, the continued growth of MRS's investment portfolio, major new initiatives under way, and MRS's superior grade on its ultimate report card, the 1996 Audit. You will be pleased to know that dues and registration fees have not risen for the fourth year in a row. The bottom line is the value delivered by the Society for the investment in time and money it makes.

\section{Operating and Consolidated Returns End Strongly}

In 1996, the net operating income was $\$ 356$ thousand, or $6.3 \%$ of gross operating revenue of $\$ 5.7$ million. These figures reflect a modest drop from 1995 when operating income totaled $\$ 390$ thousand, $7.3 \%$ of gross, in keeping with MRS Council's decision to taper operating returns toward a break-even point. (For 1997, the budgeted income is $3.2 \%$ in keeping with this taper.)

Similarly, MRS's 1996 consolidated income, which includes operations, symposium revenues and expenses (a break-even piece), and all investments, returned $\$ 736$ thousand, $11 \%$ of gross consolidated revenue of $\$ 6.5$ million. While this result is a drop from 1995 when MRS made $\$ 836$ thousand (14\% of gross), it is well above our consolidated budget expectation of $\$ 548$ thousand.

The Statement of Activities from the 1996 audit report can be seen in Table I. Statements of Financial Position and Cash Flow can be seen as Table II and III, respectively. The 1996 external audit, as just mentioned, was completed without major exception, and on a timely basis.

\section{Investment Policy Pays Dividends}

About two-thirds of this good news, namely $\$ 455$ thousand, derives from MRS's healthy Investment Policy, implemented in 1995. This policy, which was established to assist in providing for the long-term existence of the Society, has been a great success. The goals of that policy are (1) to invest in a prudent manner to create returns which support activities, (2) to preserve a capital base through risk policy compatible with the Society's public nature and position, and (3) to provide annual income consistent with budgetary needs. The portfolio consists of six funds, each with its own purpose:

- Operating Cash Fund (to provide adequate cash to supply normal cash needs of the Society)

- Operating Contingency Fund (to provide resources to operate for two years under a reasonable worst-case scenario)

- New Programs Fund (to provide resources to support new program ventures that meet the overall objectives of the Society)

- (Awards) Endowment Fund (to provide earnings for desired expenditures to support the awards program)

- Furniture and Equipment Fund (to provide cash for fixed-asset purchases)

- Property and Building Fund (to provide resources for building or real estate purchases or their maintenance).

The balances of these funds are shown in the Figure. The Operating Cash Fund is not a "managed investment fund" like the others but instead is held in liquid assets as a kind of checking account repeatedly used by MRS headquarters. Also, no money had been allocated to the Property and Building Fund at the time of approval for our new building, for which a mortgage is being sought for the reasons stated in the next section.

MRS's portfolio returned $12.7 \%$, prompting Investments Advisor Mike Bigley to call 1995-1996 "one of the most impressive two-year periods of all time" for the domestic equity mar- kets. He sets a high bar for his money managers, asking them to achieve returns benchmarked to the S\&P 500, the Dow Jones Global-World, and other indices. In 1996 that target was 13.3\%, so our portfolio (which consists of diverse investments) was slightly below this near-term target but well above our budget and longterm target of $9.2 \%$.

\section{New Initiatives}

It is exciting to see how we have begun to deploy, under Carl Thompson's able presidency in 1996, our growing resources toward the long-term good of our members. Foremost among these initiatives is our commitment to build a new headquarters building scheduled to open in the Fall of 1997. The main goals for acquiring a new building are to control the long-term management costs of the Society while increasing operating flexibility to adjust for changing customer demand, such as rewiring to meet increasing electronic delivery needs. Not only has the headquarters building project gotten off to a smooth start with ground breaking in April, but you can follow its progress on the MRS website (http: / / www. mrs.org/geninfo/building/).

To finance this $\$ 2.3$ million construction project, MRS strategy is to borrow the money at $6 \%$, which is possible owing to the outstanding performance of its investment portfolio. The investment earnings thus saved could be substantial. As market and interest conditions change, of course, this strategy will be reassessed.

Another initiative approved in 1996 is to move part or all of the Fall Meeting into the Hynes Convention Center in Boston as soon as possible. (Contracts for the first available opening and future years are being negotiated by dedicated HQ staff Gail Oare, Director of Meetings, and John Ballance, Executive Director.) While the Hynes Convention Center will cost more than the current three-hotel arrangement, the anticipated improvement in the meetings make the move well worth it. Moreover, the concomitant increase in exhibit capacity promises to offset these additional costs. Every step of the process is being deliberated to minimize impact in MRS meeting registration fees and to ensure that the quality of the Fall Meeting continually improves.

Other initiatives approved in 1996 include a pilot "Materials Success Story," fostered by tireless Julia Phillips, chair of the Public Affairs Committee, and a new information management system under continual development.

In summary, it is useful to reflect on the progress made over the last few years in MRS services and technical meetings. For the fourth year in a row, neither dues nor registration fees have been raised. Operating margins have been cut, a planned taper toward zero, while still being strong enough to enable a new electronic abstract submission system, finance a new building, and implement a new headquarters computer system. MRS meetings continue to draw attendees in record numbers even as abstract rejection rates increase. With so many positive vectors, it is hard not to be optimistic.

Yet even with all of these activities and successes, there remains delightful financial opportunity to consider other exciting projects for the good of the Society. We must all lend our most innovative thinking for bold ways to improve technical, educational, and administrative aspects of the Society. I invite you to e-mail ideas, thoughts, questions, or concerns to ajhurd@sandia.gov.

Respectfully submitted,

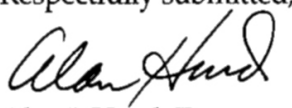

Alan J. Hurd, Treasurer 
MATERIALS RESEARCH SOCIETY

Statements of Activities (Income Statement)

Years Ended December 31, 1996 and 1995

UNRESTRICTED NET ASSETS

Revenue, Gains, and Other Support:

Meeting and seminar registration

Proceedings sales

Subscriptions

Membership dues

Education

Exhibit income

Advertising

Contributions

Mailing list rental

Miscellaneous income

Federal financial assistance

Other government funding

Corporate funding of symposia

Investments:

Investment income

Net unrealized gain on investments

Net realized gains on investments

\begin{tabular}{|c|c|}
\hline 1996 & 1995 \\
\hline$\$ 1,798,454$ & $\$ 1,620,454$ \\
\hline $1,174,497$ & $1,164,867$ \\
\hline 799,906 & 690,465 \\
\hline 370,498 & 380,586 \\
\hline 20,650 & 53,932 \\
\hline 490,878 & 461,261 \\
\hline 418,760 & 392,103 \\
\hline 96,840 & 80,408 \\
\hline 128,374 & 116,226 \\
\hline 140,288 & 139,748 \\
\hline 104,500 & 120,098 \\
\hline 116,375 & 103,250 \\
\hline 164,988 & 216,882 \\
\hline 155,675 & 138,185 \\
\hline 292,765 & 295,921 \\
\hline 30,590 & 24,154 \\
\hline $6,304,038$ & $5,998,540$ \\
\hline
\end{tabular}

TOTAL REVENUE, GAINS, AND OTHER SUPPORT

Expenses:

Program Services

Meetings

Proceedings

Subscriptions

Membership

Education

Symposia

Awards

Supporting Services

Management and general

TOTAL EXPENSES

INCREASE IN UNRESTRICTED NET ASSETS

BEFORE CUMULATIVE EFFECT OF A

CHANGE IN ACCOUNTING PRINCIPLE

Cumulative effect on prior year of a change in method of accounting for contributions

INCREASE IN NET ASSETS

Net Assets at Beginning of Year

Net Assets at End of Year

\begin{tabular}{rr}
899,333 & 800,303 \\
719,747 & 728,002 \\
745,326 & 664,285 \\
418,397 & 477,295 \\
21,773 & 47,648 \\
209,609 & 223,219 \\
39,845 & 35,294 \\
\hline $3,054,030$ & $2,976,046$ \\
$2,522,719$ & $2,200,558$ \\
\hline $5,576,749$ & $5,176,604$
\end{tabular}

\begin{tabular}{|c|c|}
\hline 727,289 & 821,936 \\
\hline - & 13,649 \\
\hline 727,289 & 835,585 \\
\hline $4,262,253$ & $3,426,668$ \\
\hline 989,5 & 4 ?6? \\
\hline
\end{tabular}

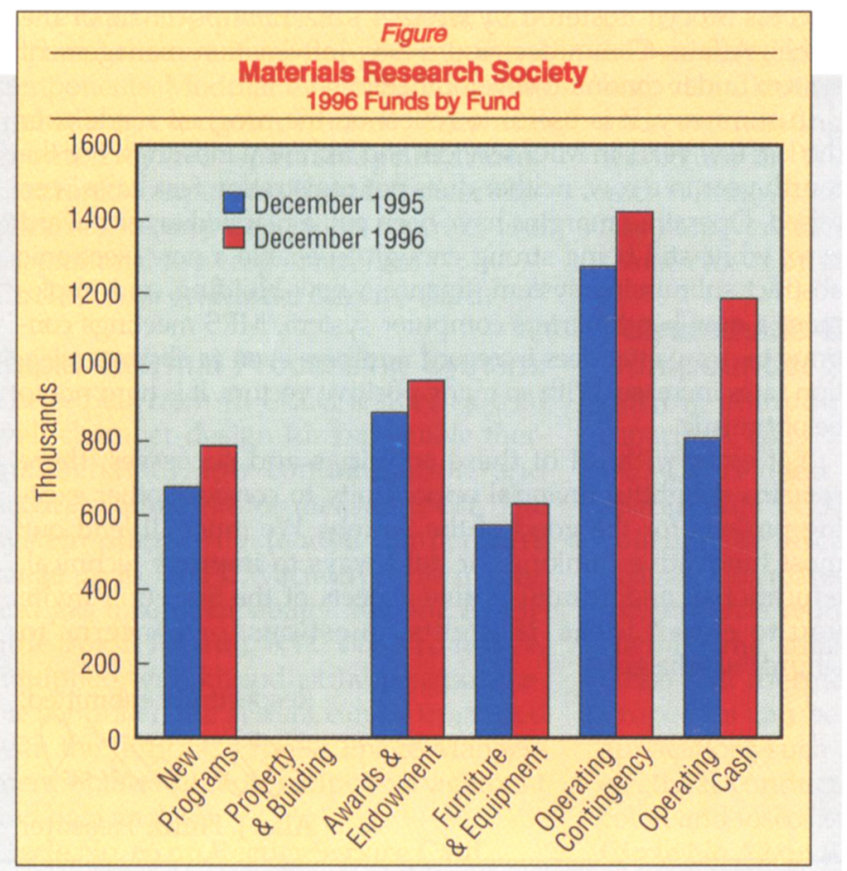

MATERIALS RESEARCH SOCIETY

Statements of Financial Position (Balance Sheet)

December 31, 1996 and 1995

\section{Current Assets}

ASSETS

Cash and cash equivalents

Investments, at fair value

Accounts receivable, net

Inventories, net

Government grants receivable

Prepaid expenses

Accrued interest receivable

TOTAL CURRENT ASSETS

\begin{tabular}{|c|c|c|}
\hline 1996 & & 1995 \\
\hline$\$ 1,186,783$ & $\$$ & 897,999 \\
\hline $3,786,822$ & & $3,282,886$ \\
\hline 567,715 & & 651,66 \\
\hline 243,082 & & 281 \\
\hline 60,229 & & 64,8 \\
\hline 95,168 & & 52,67 \\
\hline 29,432 & & 23,46 \\
\hline $5,969,231$ & & 254 \\
\hline
\end{tabular}

\section{Fixed Assets}

Data processing equipment and software $\quad 858,402 \quad 732,593$

Furniture and office equipment

Construction-in-process

306,121

85,936

$1,250,459$

751,793

Less: accumulated depreciation

498,666

TOTAL ASSETS

$\$ 6,467,897$

\section{LIABILITIES AND NET ASSETS}

Current Liabilities

Accounts payable and accrued expense

Withheld and accrued payroll taxes

Accrued retirement plan contribution

Deferred revenues

TOTAL CURRENT LIABILITIES

$\$ 530,083$

7,769

23,613

916,890

$1,478,355$

15,340

21,705

820,590

$1,391,754$

Net Assets

Unrestricted

Permanently restricted

$4,901,087$

$4,173,798$

TOTAL NET ASSETS

88,455

TOTAL LIABILITIES AND NET ASSETS

$4,989,542$

88,455

$4,262,253$

$\$ 5,654,007$

Table III

MATERIALS RESEARCH SOCIETY
Statements of Cash Flows
Years Ended December 31, 1996 and 1995

\section{Operations:}

Increase in net assets

Adjustments to reconcile change in net

assets to net cash provided by

operating activities

Depreciation

Net realized gains on investments

Unrealized (gain) loss on investments

Provision for uncollectible accounts

Provision for inventory obsolescence

(Increase) decrease in:

Accounts receivable

Inventories

Government grants receivable

Prepaid expenses

Accrued interest receivable

Increase (decrease) in:

Accounts payable and accrued expenses

Withheld and accrued payroll taxes

Accrued retirement plan contribution

Deferred revenues

Net Cash Provided by Operations

1996

$\$ 727,289$

1995

835,585

37,395

$(30,590)$

$(292,765)$

75,800

54,000

8,152

$(15,748$

4,655

$(42,491)$

$(5,969)$

$(4,036)$

$(7,571)$

1,908

96,300

706,329

114,845

$(24,154)$

$(295,921)$

23,265

91,559

$(183,648)$

$(63,287)$

$(14,139)$

32,177

$(23,463)$

134,918

37

3,171

9,133

640,078

Investment Activities:

Proceeds from sales of investments

Purchase of investments

Purchase of fixed assets

Net Cash Used by Investment Activities

Net Increase (Decrease) in Cash and Cash Equivalents

Cash and Cash Equivalents at Beginning of Year

Cash and Cash Equivalents at End of Year

846,889

$(1,027,470$

$(236,964)$

$(2,992,618)$

$(173,167)$

$(2,732,566)$

288,784

$(2,092,488)$

$2,990,487$

$\$ 897,999$ 